Cristina Quesada Padrón

hellocristinaquesada@gmail.com Universidad de la Laguna

(Recibido: 14 enero 2020/ Received: $14^{\text {th }}$ January 2020) (Aceptado: 4 mayo 2020 / Accepted: $4^{\text {th }}$ May 2020)

\section{BILDERBOKEN: A BRIEF STORY AND CHARACTERISTICS OF SWEDISH PICTURE BOOKS}

\author{
BILDERBOKEN: BREVE HISTORIA Y \\ CARACTERISTICAS DEL ÁLBUM \\ ILUSTRADO SUECO
}

\begin{abstract}
This article addresses a brief journey throughout the picturebook in Sweden, which starts with a definition of picture books and their characteristics according to different professionals. Some of them have developed their research activity in the Nordic countries, such as Ulla Rhedin or Maria Nikolajeva. Next, an introduction to the research of this material in Sweden has been developed chronologically followed by a brief story of Swedish picture books. Then, after the study of different works published by researchers and associations, and after the reading of numerous Swedish picture books, the peculiarities of Swedish picture books will be explained, followed by examples of books, authors, and illustrators. Furthermore, different associations and institutions that encourage and promote children's literature in Sweden will be mentioned, accompanied by their functions, which can include the preparation of different activities, the organization of literary awards, or the participation in congresses and conferences.
\end{abstract}

Keywords: Picture book; Illustration; Children's literature; Swedish children's literature.

\title{
Resumen
}

Este artículo aborda un breve recorrido por el álbum ilustrado en Suecia, que empieza por una definición del concepto "álbum ilustrado" y una presentación de sus características de acuerdo con distintos profesionales, de los cuales algunos han desarrollado su actividad investigadora en los países nórdicos, como es el caso de Ulla Rhedin y Maria Nikolajeva. A continuación, se expone una introducción a la investigación sobre este recurso en Suecia presentada de manera cronológica, desde los primeros avances hasta la actualidad, así como una breve historia del álbum ilustrado sueco. Seguidamente, tras el estudio de distintas publicaciones divulgadas por investigadores y asociaciones, así como tras la lectura de numerosos álbumes ilustrados suecos, se exponen las peculiaridades de este y una serie de temas recurrentes que lo caracterizan, acompañadas de varios ejemplos de librosálbum y de sus autores e ilustradores. También se mencionan algunas de las distintas asociaciones e instituciones que fomentan y promocionan la literatura infantil en Suecia y las funciones que estas 
desempeñan, las cuales incluyen tanto la organización de numerosas actividades como la entrega de distintos premios o la participación en diversos congresos y conferencias.

Palabras clave: Álbum ilustrado; Libro-álbum; Literatura infantil y juvenil; Literatura infantil sueca.

\section{Introduction}

Children's literature in Sweden plays a very significant role and is enjoyed by a high number of people in both school and family environments. According to information provided by the Swedish Institute for Children's Books, the Svenska Barnboksinstitutet (SBI) (2018: 5), in 2017, 2,532 books addressed to children and young people were published in Sweden, which means that in the $21^{\text {st }}$ century the publication of children's literature is more than twice as high as in the past. In particular, picture books have acquired more attention; and it has become the broadest publishing category, whose publication has noticeably increased (Svenska Barnboksinstitutet, 2018: 5).

The increasing production of picture books in Sweden during the last decades has made that today these are considered as an important part of the Swedish culture. Local authors and illustrators such as Sven Nordqvist, Jujja Wieslander, or Emma Adbåge and their books are well known and loved by children and adults. Swedish picture books are characterized by bringing children closer to themes that are not usually talked with them, and by telling stories that amuse the youngest ones and sometimes can scandalize those adults that insist on maintaining children's innocence. Swedish picture books, far from being typified by sweetened stories, focus on entertaining, helping children understand the world that surrounds them, as well as including characters and situations that are not traditionally represented in this medium. This, together with the support that children's literature receives in Sweden, converts them into an important field of study. These characteristics have inspired the theme of this article, whose aim is to provide an overview of Swedish picture books through the study of several publications as well as through the analysis of different subjects that are frequently tackled in these books, that are at their peak and that are enjoyed by a varied audience.

Picture books have been the focus of different research works published by children's literature scholars such as Maria Nikolajeva, Ulla Rhedin, Lena Kåreland, Kristin Hallberg (Sweden); Teresa Colomer, Emma Bosch, Jesús Díaz Armas, Teresa Durán, Cecilia Silva Díaz (Spain); Ellen Handler Spitz, Barbara Bader (United States); Perry Nodelman (Canada); Martin Salisbury and Morag Styles (United Kingdom); Sophie Van der Linden, Isabelle Niéres-Chevrel (France); Ana Margarida Ramos, Carina Rodrigues (Portugal) or Bettina Kümmerling-Meibauer (Germany), among others.

In picture books, text and illustrations, together with every other element that is part of the book, are equally responsible for the narration of the story (Rhedin, Oscar K., Eriksson, 2013) and are interdependent. This combination causes that the narration cannot be fully understood through reading only the words or interpreting only the pictures. The picture book is not only formed by text and illustrations but by other components such as the paratexts, the flyleaves, the cover, or the typography, which makes it be considered as a multimodal material (Moya \& Pinar, 2007).

Something that characterizes these books is that they can be read several times because there are always new interpretations and experiences that can be discovered with each read (Rhedin, Oscar K., Eriksson, 2013). This shows that even those picture books that might seem simple can actually be quite complex (Kümmerling-Meibauer, 2017) they are "often, both much simpler and richer and more complicated than texts for older children, or even for young adults" (Nodelman, 2017: 10) A classic 
example of a popularly mentioned picture book is Where the Wild Things Are, by Maurice Sendak (1963). One of the first and most spread definitions of picture books is the one created by Barbara Bader in her book American Picture books from Noah's Ark to the Beast Within (1976: 1):

A picture book is text, illustrations, total design; an item of manufacture and a commercial product; a social, cultural, historical document; and foremost, an experience for the child. As an art form it hinges on the interdependence of pictures and words, on the simultaneous display of two facing pages, and on the drama of turning the page. On its own terms its possibilities are limitless. (Bader, 1976: 1)

There is a clear difference between picture books and illustrated books, both often called bilderboken in Swedish. The second type refers to a book that lacks the interdependency of words and pictures and, instead, the text carries the most substantial weight of the narration, which causes that the images can get into redundancy and might even seem dispensable. Often, the pictures represent a situation that has been described in the narration and might even add some additional information, but usually those illustrations are not essential for the understanding of the story.

According to Nikolajeva and Scott (2001: 8), the text-image dynamics in literature has two different ends: "a book of text without pictures and a book of pictures without text." The far side of the second spectrum is formed by the so-called silent books, in Swedish textlösa bilderböcker or ordlösa bilderböcker, which are picture books that tell stories only or nearly only through illustrations and that have very few words or none at all. One of the most famous silent books is The Snowman, by the English illustrator and author Raymond Briggs (1978). In Sweden, this type of book has also been published, such as Hundpromenaden, by Sven Nordqvist (2018) or Limpan är sugen, by Eva Lindström (1997), among many others.

\section{Picture books in Sweden}

In Sweden, the first research activity regarding picture books was registered in the decade of the 70s, due to publications that accomplished an analysis of these type of books and of the text-image relationship, as in the case of Bilden i barnboken, by Lena Fridell (1977), which includes the chapter Bilderbok och bildanalys by Gustaf Cavallius (Rhedin, 1992: 17). This multidisciplinary publication was inspired by the anthology Aspekte der gemalten welt [Aspects of the pictured world], published in the late 60s by a group of German researchers, and that entailed a basis for the research in illustrated books (Rhedin, 1992: 17).

In the 80s, there was an emergence of new research publications focused on picture books as an art form in which images and text were equally important for the narration. Some of these studies were Litteraturvetenskapen och bilderboksforskningen, by Kristin Hallberg (1982) and the anthology I bilderbokens värld (1985), by Kristin Hallberg and Boel Westin. However, probably the doctoral thesis Bilderboken- på väg mot en teori, by the Swedish researcher Ulla Rhedin (1992), Doctor of Literature, set an example for the subsequent studies in picture books in Sweden, as it was the first doctoral thesis about picture books to be published in the Nordic countries (Druker, 2018: 2). In her thesis, she formulated a definition of a picture book, concluding with its classification in three different categories, which would be subsequently analyzed by other researchers, such as Maria Nikolajeva. 
The Swedish term bilderbok can be translated as "picture book." This word is generally used to encompass picture books as much as illustrated books, which might confuse when searching for information about this material since sometimes, when using this concept, the reference is illustrated books instead of picture books. Moreover, this can also lead to misunderstanding when looking for these books in bookshops and libraries, even in the titles of the books themselves. An example is the classic Känner du Pippi Långstrump? [Do you know Pippi Longstocking?] by Astrid Lindgren and Ingrid Nyman, published for the first time in 1947 and whose subtitle is Bilderbok av Astrid Lindgren och Ingrid Nyman [A picture book by Astrid Lindgren and Ingrid Nyman]. Even though this book is described in its subtitle as a bilderbok, it does not meet the requirements to be considered what Rhedin would call "a genuine picture book" due to the symmetrical relation of both text and images, which makes it rather an illustrated book than a picture book. It does include text and appealing illustrations on each spread that show some physical characteristics of Pippi and her house Villa Villekulla, but the majority of those pictures are limited to illustrate what has already been narrated in the text. This means that the story is fundamentally told by the words and could even be understood without looking at the pictures.

As mentioned before, in the field of picture book studies in Sweden, Ulla Rhedin's doctoral thesis Bilderboken -på väg mot en teori [Picture books -towards a theory] (1992) meant an important basis. This is partly due to the classification into three categories of illustrated books, which was one of the first ones to be presented by a Swedish children's literature researcher. Even though her categorization has been discussed throughout the years and has been considered by some researchers to be incomplete and insufficient, there is no doubt that it was essential for the following research studies in Sweden. In the thesis, Rhedin (1992: 81), uses the word bilderbok to encompass the different type of books with illustrations and marks that this term is divided into three different concepts depending on the relation of the images with the text. First, the illustrated text (den illustrerade texten), according to Rhedin (1992: 271), constitutes the oldest and most traditional concept of the illustrated book and has a complete, independent and dominant text that is created without "knowledge of the illustrations" that will accompany it and that, therefore, does not need them in order to transmit the narrative message. They are rich texts that can quickly produce "mental images" in the reader, which turns them into complete stories. The reader can understand the story without interpreting the illustrations, as these do not add any additional information nor contradict the meaning of the narration. According to Rhedin (1992: 77), an example of this type of illustrated book is Titta, Madicken, det snöar!, by Astrid Lindgren (1983).

Then, there is the expanded text (den expanderande texten), about which Ulla Rhedin (1992: 88) states that it is written to complete the narrative message due to the illustrations. The texts in these types of books are usually "short, laconic" and more similar to "a poem or the synopsis of a film" (Rhedin, 1992: 272). Generally, they do need to be complemented so that they can be understood entirely. The illustrator and the author usually create a real situation first, and then they decide what moments and details to illustrate. "The illustrator often chooses the artistic approach" regarding the text with freedom, for example, by expanding it or interpreting it in a personal way and creating pictures from that reading (Rhedin, 1992: 272). This relationship of these two communication levels can coincide with the descriptive function of the illustrations regarding the text, as in the illustrated text described in the definition of the illustrated book. However, in this concept, the picture fulfills a more emphasized role (Rhedin, 1992: 272). In the stories where the protagonists of the narration are people, their characteristics are illustrated through techniques such as facial expression, kinetic 
signs, body language, their appearance concerning their ages or other physical characteristics. As an example of a book that reflects this concept, Rhedin (1992: 78) mentions Vilda bebin fär en hund, by Barbro Lindgren and Eva Eriksson (1985).

Last, Rhedin (1992: 96) refers to genuine picture books, which in Swedish she calls den genuina bilderboken. This is a multimodal material in which the text is no longer primary or superior to the images, as both elements are essential for the story, that is created by an author-illustrator or by an author and an illustrator, who introduce their joint vision of the narration in the book. An authentic picture book is, therefore, much more than a book composed of a text that is illustrated with dispensable pictures since the story depends on both the text and the illustrations to complete its meaning (Rhedin, 1992: 272). If one of these elements is omitted, the story is not complete and, therefore, it cannot be fully understood. The picture is used in different ways to complete the narrative action.

Moreover, the complete design of the book, which includes the typography, the margins, among other elements, and the dramatic tool of expression known as "the drama of turning the page," is also an essential part of the narration (Rhedin, 1992: 272). Many times, this is the type of books which adults read to children for the first time, which consists of images and words and that can be read in short periods of times. Its visual and verbal narrative components can produce different narrative interpretations and can even sometimes cause contradiction, which turns it into an intricate literary work (Rhedin, 1992: 272). As examples of genuine picture books, Rhedin (1992: 272) mentions those written by Maurice Sendak, or the Swedish authors Thomas and Anna Clara Tidholm.

The Swedish researcher on children's literature Maria Nikolajeva, together with Carole Scott (2001: 7), explains that even though Rhedin's classification entails a good starting point, the reality is that it is insufficient and artificial. Both authors explain that even if they can accept the first category of the illustrated text, they consider that the differences between the two last ones are "very subtle" and even "subjective", as Rhedin does not suggest clear guidelines after presenting two picture books as examples (Nikolajeva, Scott, 2001: 7). Furthermore, they consider that her classification does not cover enough the critical interdependency of the illustrations with the text and that more categories and levels are needed in order to classify the different types of picture books (Nikolajeva, Scott, 2001: 7).

In both her books Bilderbokens pusselbitar (2000: 22-26) and How Picture books Work (2001: 12), this last one written together with Carole Scott and that constitutes one of the most prominent reference works in picture books studies, Maria Nikolajeva (2000: 22), who has developed part of her research activity in Sweden, distinguishes five different categories. The first one is "the symmetrical picture book," which has two parallel narrations, a verbal one and a visual one, that complement each other and that reciprocally provide some additional information but that narrate the same story and tend to be redundant. The second is "the complementary picture book," in which the text and the illustrations mutually complement and cover the gaps that each narration might have. In the third one, "the expanding picture book," the text is very dependent on the illustrations and vice versa, which leads both levels of communication to be indispensable. The fourth category, "the counterpointing picture book," as its name indicates, is formed by text and illustrations that share an ironic relationship that can be produced, for instance, because the text narrates some facts, but the pictures show different ones. This contradiction requires the active participation of the reader in order to develop different interpretations of the narration. Last, the "sylleptic picture book," is related to the previous category, but in this case, it reaches a conflict in which illustrations and words do not correspond 
to each other, which can make the reader feel insecurity and confusion when interpreting the story (Nikolajeva, 2000: 22).

In this article, the vast majority of the picture books that will be mentioned will be those that would be considered as complementary, expanding, counterpointing and sylleptic picture books, according to Nikolajeva's classification; and expanding and genuine, according to Rhedin's classification. These types of picture books will often be referred to as "contemporary picture books" or "modern picture books."

Picture books are books that adapt to new generations (Druker, 2008). The modernity of the contemporary picture book is due to the fact that sometimes they bring about feelings of oddness and rejection to adults because of the descriptions of different aspects of childhood, some of them darker than others: "they are symbolic, expressive, ambiguous and multivalent. They dare to express the horrors and fears of childhood and life in a direct, child-orientated, non-pedagogic, non-explanatory way" (Rhedin, 1992: 273).

Moreover, the themes that this type of book encompasses, together with the complexity of the relationship between images and text, suggest that picture books are no longer addressed only to the youngest children but that they can also be enjoyed by readers of any age (Rhedin, 1992: 273) as it connects with its double reader -children and adults- through different levels. This is something that characterizes Swedish picture books. As it will be explained later, these books not only aim to entertain children but also are written covering a broad spectrum of themes that expresses complicated feelings and situations that help children understand the world that surrounds them.

Nowadays, several institutions and associations in Sweden encourage children's literature, both nationally and internationally. The Svenska barnboksinstitutet (SBI) [The Swedish Institute for Children's Books] opened for the first time in 1967, which meant that children's literature was something that could be studied and researched in university (Kåreland, 2013: 16). Since 1993, the SBI annually publishes a document called Bokprovning [Book tasting] with different analyses and statistics of the children's books published in the previous year (Svenska Barnboksinstitutet, 2018: 6). The fact that since 2000 the SBI decided to divulge these documents that were initially addressed only to librarians and researchers of this matter (Svenska Barnboksinstitutet, 2018: 6) allowed everyone interested in children's literature for discovering the new publications, authors and artists that emerge each year.

The Svenska Barnboksakademin [The Swedish Academy for Children's Books], which has worked since 1989 on the promotion of quality children's books, also plays a significant role. So does the Swedish Section of IBBY, which annually organizes the Gulliver Prize and the Peter Pan Prize, and which was responsible for the Silent Books Project that took place in Sweden between 2013 and 2017. In this project, different silent books from different countries were gathered in order to use them in collaboration with libraries and refugee centers in Sweden, to provide immigrant children with an inspiring experience through the use of books that can be understood with disregard of their mother tongue.

Furthermore, public libraries in Sweden also are indispensable for the popularity and promotion of picture books and children's literature in general due to their extensive catalogs of books, their numerous facilities and the different activities organized in them, which turns them into cultural centers suitable for the entire family.

To end, two other influential events that support and encourage children's literature in Sweden are the Göteborg Book Fair, celebrated each year in Gothenburg, and which is considered 
to be Scandinavia's largest cultural event, formed by different seminars, conferences, exhibitors and other activities for people of all ages; and the world's largest children's literature award, the Astrid Lindgren Memorial Award (ALMA), administered by the Swedish Arts Council and which is presented each year to illustrators, authors and other people or institutions that promote reading. Some of the laureates from 2003 until today have been Maurice Sendak, Kitty Crowther, and Wolf Erlbruch.

\section{A brief story of picture books in Sweden}

The term bilderbok, which comes from the German bilderbuch, appeared on the title of a book for the first time in 1825, in a book called En liten bilderbok för barn [A little illustrated book for children] translated from German and that included small illustrations of plants, animals, and objects (Kåreland, 2002: 63). However, the term bilderbok was established adequately around 1860, "when it became possible to print picture books reasonably easy and cheaply" and, in this case, they were "books with one or more illustrations on each spread" (Kåreland, 2013: 7).

Lena Kåreland, a Swedish researcher in children's literature, has written several publications about the story of children's literature and picture books in Sweden. In fact, since 2009 she participates in a project created by the Svenska Barnboksinstitutet, in which she collaborates in the composition of the story of children's literature in Sweden, named Den svenska barn-och ungdomslitteraturens historia [The Story of Swedish children's literature], together with Elina Druker, Janina Orlov, Ulf Boëthius and Boel Westin as the chief editor and that is in its final phase. Two of Kåreland's publications that have already been divulged are Barnlitteraturens utveckling i Sverige (2008) and The Story of Swedish Picture books (2013), the second written as an introduction to the publication created to represent Sweden in the Bologna Children's Book Fair in 2013, which was the year when Sweden was Guest of Honour. In one of these publications, Kåreland (2013: 7) states that at the end of the 19th century, due to the development of "new printing techniques," it became possible to produce a vast number of illustrated books. These books were manufactured by new artists that were beginning to focus on illustration, and a great number of readers applied (Kåreland, 2013: 7). However, initially, the copies produced were limited, and they tended to be big, massive and hardcover (Kåreland, 2013: 7). They usually could only be afforded by readers of the middle-class, whereas magazines and newspapers edited in Christmas permitted illustrators such as Ottilia Adelbog or Jenny Nyström to reach a more extensive number of readers (Kåreland, 2013: 7).

One of the first Swedish illustrated books was Barnkammarens bok, published in 1882: a book of rhymes and songs that highlighted the Swedish traditions and scenery completed with illustrations by Jenny Nyström, one of the most well-known artists in Scandinavia due to her illustrations in many Christmas postcards (Persson, 2006: 12). Due partly to Nyström and her success, in 1900, there was an emergence of new artists that followed in her footsteps, such as Elsa Beskow (Persson, 2006: 12), who was probably the most famous children's illustrator of her time.

Despite the presence of illustrated books in Sweden since before 1900, the Danish modern illustrated books that were translated into Swedish after the Second World War inspired what today is considered to be the modern Swedish picture book (Torppa, 2006: 2; Druker, 2008). Something that distinguished these from the ones previously published in Sweden was that the creators of these books wrote stories that revolved around children characters (Torppa, 2006: 12).

Moreover, during the decades of the 40s and 50s, Nordic authors changed the narrative and the aesthetic, as they considered that the traditional illustrated book did not adapt to children's 
situation in the modern society of that time (Druker, 2010: 139). Some examples of these picture books were the ones created by authors such as Inger and Lasse Sandberg, Lennart Hellsing or Stig Lindberg, which had minimalistic texts and simple illustrations. This fact offered an alternative art form being an inspiration for many of the contemporary picture books (Druker, 2010: 147).

Astrid Lindgren, whose bibliography is very extensive and who is one of the most well-known figures of children's literature, was a reference for following publications as her books showed stories of daily life as well as situations that seemed familiar to children and that they could easily relate to due to the prominence of children figures as main characters. A clear example is the books of Pippi Longstocking, published for the first time in 1945.

About the vital presence of children in picture books, which begins to arise in the 40s, Druker (2010: 148) states that the figure of the child became "a metaphor for progress and development -they became representatives of a better future."

Contemporary Swedish picture books appeared in the 80s and 90s, due to new artists and authors that were eager to experiment and innovate, and who updated it and created books whose narrations would be developed by illustrations and text. This new picture book, which can be "poetic, dramatic and expressive" (Rhedin, 1992: 13), developed a dynamic relationship of both levels of communication: the text, and the image, which became more complex and profound. Furthermore, this type of publication that was fundamentally dedicated to children began to be addressed to readers of all ages.

As to Swedish silent books, they are likely to have appeared during these decades of the 80s and 90s. Probably one of the first well-known Swedish silent picture books is Limpan är sugen, by Eva Lindström, published in 1997. This one was followed by other more recent silent picture books such as På djupet, by Jenny Karlsson (2008), Fröet, by Jennie Ekström (2016), or Hundpromenaden, by Sven Nordqvist (2018), besides the more recent versions of Pippi Långstrump's stories published as board books without text, among others.

Something that characterizes contemporary Swedish picture books is the ability of authors and illustrators to address all types of subjects independent of the ages of the reader. As said, the broached themes are varied, such as problems of daily life and even existential questions that, generally, might seem complicated to tackle, and that can even cause controversy. The moral and didactic messages that characterized the first illustrated books, which meant to educate children, are no longer a part of the modern picture books. Instead, they try to provide a view of children and the place they occupy in contemporary society, as well as offering the experience of observing the beauty of the illustrations (Kåreland, 2013: 8).

Current Swedish picture books are characterized by maintaining a tight connection with the problems and ideas of contemporary society. It reflects engagement in favor of social inclusion (Svenska Barnboksinstitutet, 2018: 5), and it frequently broaches subjects that can be considered to be complicated to address, especially with the youngest ones, but that sooner or later need to be tackled so that children understand the world around them. As mentioned before, these picture books are not only addressed to children, as they often have a message to adults, which are the ones that many times read these books to children.

They tackle themes such as gender equality, the new family patterns, and the individuality of parental figures. Another subject that acquires importance is gender identity, which today is at its peak. In Sweden, it started to become popular at the beginning of the $21^{\text {st }}$ century. Then, different media started to analyze the feminine and male roles in children's literature: male characters predominated, 
and these tended to carry qualities such as strength or courage, whereas female characters tended to be kind and obedient (Kåreland, 2013: 18).

These gender patterns, which can be considered to be classic, also followed a model on the correlation of colors to a determined gender: pink was for girls and blue was for boys. This has changed a lot in the modern Swedish picture book, and today there are not only more male and female figures that do not have the features that they were often given and that can, therefore, be courageous, strong and also insecure and calm, but there has been an emergence of characters of unknown gender.

A clear example is Pom och Pim, by Lena and Olof Landström (2012), in which the main character is a child and their stuffed toy. The gender identity of Pom cannot be guessed by their clothes, or the colors in their clothes, by their hair, their behavior, nor even by their name, and it makes it easier for children to feel identified with them.

Pija Lindenbaum, like many other illustrators and authors, also creates stories and characters keeping social diversity in mind. One of her books, Kenta och Barbisarna (2007), tackles a theme that is being frequently debated today -sexism in toys- by creating the figure of Kenta, a boy that likes to play football but that also enjoys playing with dolls.

Moreover, in Swedish, besides the personal pronouns "han" for masculine and "hon" for the feminine, a new neutral pronoun has been created to refer to those people that do not feel identified with the binary pronouns or to make a reference to someone without having to specify their gender. This pronoun is "hen," which would be the equivalent to the singular they pronoun in English. Since its acknowledgment in 2015 by the Svenska Akademiens Ordboken, the Swedish Academy Dictionary (SAOL, 2018), it has started to be used in several texts and publications. The first children's book in making use of this pronoun was Kivi och monsterhund, by Jesper Lundqvist and Bettina Johansson (2012). As in Pom och Pim, the gender of the child is unknown.

Even though there was a previous predominance of male figures in children's literature, today there is a prominent presence of feminine protagonists (Svenska Barnboksinstitutet, 2018: 5). This can be seen in the collection of picture books about Mamma Mu by Jujja and Tomas Wieslander and Sven Nordqvist (1993-2018), or in many of the picture books written and illustrated by Emma Adbåge, such as Jag är jag (2011a) or Leni blir en bebis (2011b).

Many of the characteristics of the parental figures that are present in current Swedish picture books are the result of several debates that began to take place in the 60s in Sweden regarding women's freedom and gender equality (Kåreland, 2013: 16). These discussions led to the appearance of new family patterns formed by divorced parents, single parents, a new figure of the father as a person that is a househusband and that takes care of the housework, and a new figure of the mother as an independent woman, everything followed by a decrease of parental authoritarian character (Kåreland, 2013: 16).

This fact can be observed in different books, as in the collection of Bosse och Bella, by Måns Gahrton and Amanda Eriksson (2012-2018), in which both parental characters are involved in the education of their children but without an apparent disciplinary personality. Also in En dag med Johnny, by Bo R. Holmberg and Eva Eriksson (2002), about a boy who spends a day with his father, who lives in another town; or in the illustrated books and picture books of Alfons Åberg, by Gunilla Bergström, published for the first time in 1972 and that narrate different situations of the life of a boy named Alfons who lives with his father. 
Together with the different family patterns, sexual diversity is also a subject that is being tackled in contemporary Swedish picture books. Probably, one of the first ones in including a family made up of homosexual parents was Malins mamma gifter sig med Lisa, by Annette Lundborg and Mimmi Tollerup -Grkovic (1999). In this picture book, the protagonists are the mother of Malin and her partner Lisa, with whom she is going to get married. However, as it happens in other books such as Pinsamt värre, Krille! by Åsa Karsin and Karin Bektasevic (2012), also about a boy and his two mothers or Kompisen i hissen, by Minette Lidberg and Jesper Jenemark (2017), whose protagonist has two fathers, the sexual orientation of these characters is not commented as it is considered to be natural.

Moreover, there is an increasing number of picture books and informative illustrated books that explain different types of families, such as Familjeboken, by Edward Summanen (2015).

The traditional image of Sweden is still present in its picture books, something that can be seen in the series of Pettson och Findus by Sven Nordqvist, published from 1984 until today, in which Nordqvist illustrates images of the daily life in the countryside. Eminent illustrators such as Elsa Beskow probably influenced the picture of traditional Scandinavian landscapes full of forests, flowers, and idyllic fields that characterize the classic and contemporary Swedish picture books.

Moreover, even though many picture books still include Swedish elements such as landscapes, characters, or traditions, nowadays, many of them also represent a multicultural Sweden in favor of diversity and integration. Some examples are Jag älskar Manne, by Pija Lindenbaum (2012), Tutu och Tant Kotla har kul!, by Gunna Grähs (2008), or Kompisen i hissen, by Jesper Jenemark (2017), whose main characters are children and adults of different ethnic groups.

There is also an increase in the publication of books that encourage respect and tolerance, which is the case of Vem är du? En bok om tolerans, by Pernilla Stalfelt (2012). This book portrays multiculturalism through many different characters.

Moreover, the recent wave of refugees that Europe has undergone during the last years has inspired the publication of picture books that show the experiences of different characters escaping from their hometowns seeking for a better future (Svenska Barnboksinstitutet, 2018: 10). Regarding this theme, some Swedish ones have been published, such as Jag kom hit på ett litet blad, by Sarah Vegna and Maya Jönsson (2017), as well as translations such as The Day War Came, by Nicola Davies and Rebecca Cobb (2018), initially published in English.

Swedish picture books also experiment an increase in the inclusion of stories and characters that have different characteristics and personalities. Some of them are relatively new, such as Låtsasheten, by Nathalie Ruejas Jonson (2017), in which a boy explains what it feels like to be introverted; Den ovanligaste barnen i världen, by Inger Edelfeldt, and Emma Adbåge (2008), whose main characters are two eccentric parents that want their children to be as bizarre as them; or Eli har en storebror, by Karin Jacov and Jenny Sjödin (2018), about the relationship of Eli with his older brother, who has autism.

The figure of the child, which has been previously mentioned, is also an outstanding characteristic of Swedish picture books. In many cases, children are portrayed as rebel girls and boys that are not willing to follow the orders given by their parents or, generally, by any other adult. Instead they prefer to play and look for their adventures.

Probably one of the first figures in Swedish children's literature to meet these characteristics is Pippi Longstocking, the famous character created in 1941 by Astrid Lingren. Pippi represents the contrary to what would be expected from a child in general and, especially, from a girl. She is a strong girl that does not pay attention to the orders of any adult, who lives alone and does anything she wants, who is irresponsible, disobedient, and restless. In the time when Pippi's books were published 
for the first time, this character was very controversial, primarily for parents, who thought that the reading of these books would make their children aspire to be like her.

These books were followed by others with children characters, both boys and girls, who are independent, who are not afraid to be who they are nor to show their emotions and behave the way they want. Some of these are the illustrated books of Den vilda bebin, by Barbro Lindgren and Eva Eriksson (1980-1990), and other contemporary picture books such as Flickan som blev varg, by Sofia Hedman y Jenny Lucander (2014), in which a girl called Milda and her friend IIma pretend to be wolves after arguing; or Leni är en sockerhjärta, by Emma Adbåge (2017), to name a few.

One of the most complicated themes to tackle and that is recurring in Swedish picture books is death, which is generally addressed from a positive and encouraging perspective. Somehow it can answer some of the existential questions that many children have and that some parents are not able to answer. This is the case of picture books such as Sotis -en alldeles sann historia, by Ilon Wikland (2012). It narrates how a girl's cat dies after being run over by a car, her sadness after this event and her joy after discovering that a cat appeared on her door; or Adjö herr Muffin, by UIf Nilsson and Anna-Clara Tidholm (2009). UIf Nilsson has also written other picture books about death and other complicated subjects. Two of them are Alla döda små djur (2006), illustrated by Eva Eriksson, in which a group of friends thinks about all the small dead animals in the forest and then come up with the plan of creating a cemetery for them; or Farmors alla pengar (2014), also illustrated by Eriksson, a picture book based on a real personal story of the author, whose main character is a grandmother who has Alzheimer.

Pernilla Stalfelt also uses unique themes in her picture books and illustrated informative books (in Swedish, faktaböcker) about nature and the human body, created with humor and downplaying subjects that can be considered as taboo. The first book of that series that was published was Hårboken (1996), in which she explains various facts about hair. After this one, she published others with the same title but replacing the word "hair" by others such as "love," "death," or "life."

As in many other countries, picture book series about the same characters are top-rated, and there are many different ones, such as the series about Max, by Barbro Lindgren and Eva Eriksson (1981-2013), the books of Bu och Bä, by Olof and Lena Landström (1995-2013), the Vem series, by Stina Wirsén (2005-2016) or Kanin, by Lena Anderson (1986-1995). Many of the picture books in these series belong to the category of pekböcker [pointing books]. This category is called "board books" in English; it refers to those generally addressed to 0 to 2-year old children and which are usually small, made out of cardboard and that typically have a very concise text or no text at all.

\section{Conclusions}

In Sweden, according to the Svenska Barnboksinstitutet (2018: 17), picture book category is, today, the widest inside the category of children's literature, and this makes that there is an increasing number of people interested in its research and promotion. The research activities on modern Swedish picture books, accomplished by researchers such as Ulla Rhedin, Lena Kåreland, Maria Nikolajeva or Elina Druker, mean an important baseline not only for the future studies to be done on this matter, but also for the emergence of new researchers and for the discovery of new literary works which are in constant evolution and which interest more people each day.

As well as a picture book itself, the use of the Swedish term bilderbok has also progressed. Today this concept is used for referring to contemporary picture books much more than for illustrated 
books. This can also be since today, in the visual society we are living in, many of the illustrated books which are published tend to offer sophisticated relations text-image, making them rich and turning them into complex works.

Swedish children's literature has a vast number of picture books which each day acquire more popularity and importance accounting for authors and illustrators with long and successful careers such as Sven Nordqvist, Eva Lindström, or Pija Lindenbaum, and others from more recent generations such as Lisen and Emma Adbåge or Karin Cyrén among many others. No doubt that these books are outstanding and seem attractive for children and adults, both in Sweden and other countries.

There is often a preconceived idea that part of the popularity of this type of literature in Sweden is due to the numerous hours that children need to spend indoors during the winter because of the cold and the darkness. However, even though this perception can partly have some foundation, something that favors the popularity of this literature is the fact that Sweden places great importance on children's literature accounting for its constant presence in different media, where it is analyzed and valued. Awards must also be considered. For example, the Gulliver-priset or the Astrid Lindgren Memorial Award (ALMA). Also, libraries in Sweden, which besides having a wide selection of children's literature, usually organize different activities about it for an assorted public.

Moreover, Swedish literature tries very hard to make its access available to every child and to succeed in addressing varied subjects that reflect society as similar as possible to the current one: diverse and open as well as to offer the same possibilities to everyone regardless of the gender, race or any other situation. Every type of prejudice on children and young people is avoided. On the contrary, tolerance, justice, and inclusion are spread due to a type of children's literature which is at its peak and concerned about solving current society problems.

\section{REFERENCES}

\section{Primary sources}

ADBÅGE, E. (2011a). Jag är jag [l am me]. Stockholm: Rabén \& Sjögren.

ADBÅGE, E. (2011b). Lenni blir en bebis [Lenni becomes a baby]. Stockholm: Rabén $\&$ Sjögren. 2018 Edition.

ADBÅGE, E. (2017). Leni är en sockerhjärta [Lenni is a sweetheart]. Stockholm: Rabén och Sjögren.

ANDERSON, L. (1986-1995). Kanin [Rabbit]. Book series. Stockholm: Rabén \& Sjögren. 2015 Edition.

BERGSTRÖM, G. (1972-2006). Alfons Åberg. Book series. Stockholm: Rabén \& Sjögren. 2002-2017 Editions.

BRIGGS, R. (1978). The Snowman. London: Penguin Books. 1998 Edition.
DAVIES, N., COBB, R. (2018). The Day War Came. London: Walkerbooks.

EDELFELDT, I., ADBÅGE, E. (2008). De ovanligaste barnen $i$ världen [The most unusual children in the world]. Stockholm: Alfabeta.

EKSTRÖM, J. (2016). Fröet [The seed]. Stockholm: Natur och Kultur.

GAHRTON, M., ERIKSSON, A. (2012-2018). Bosse och Bella [Bosse and Bella]. Book series. Stockholm: Berghs.

GRÄHS, G. (2006). Tutu och Tant Kotla har kul! [Tutu and Aunt Kotla have fun!]. Stockholm: Alfabeta Bokförlag.

HEDMAN, S., LUCANDER, J. (2014) Flickan som blev varg [The girl that became a wolf]. Färjestaden: Vombat förlag. 
HOLMBERG, B., ERIKSSON, E. (2002). En dag med Johnny [A day with Johnny]. Stockholm: Alfabeta.

JACOV, K., SJÖDIN, J. (2018). Eli har en storebror [Eli has a big brother]. Lerum: Idus Förlag. KARLSSON, J. (2008). På djupet [In the depths]. Göteborg: Kabusa Böcker AB.

KARSIN, A., BEKTASEVIC, K. (2012). Pinsamt värre, Krille! [How embarrassing, Krille!]. Linköping: Olika.

LANDSTRÖM, L., LANDSTRÖM, O. (19952013). Bu och Bä [Bu and Ba]. Book series. Stockholm: Rabén \& Sjögren.

LANDSTRÖM, L., LANDSTRÖM, 0. (2012). Pom och Pim [Pom and Pim]. Stockholm: Lilla Piratförlaget.

LIDBERG, M., JENEMARK, J. (2017). Kompisen $i$ hissen [The buddy in the elevator]. Stockholm: Opal.

LINDENBAUM, P. (2007). Kenta och Barbisarna [Kenta and the Barbies]. Stockholm: Rabén \& Sjögren. 2010 Edition.

LINDENBAUM, P. (2012). Jag älskar Manne [I love Manne]. Stockholm: Bonnier Carlsen.

LINDGREN, A., VANG NYMAN, I. (1947). Känner du Pippi Långstrump? [Do you know Pippi Longstocking?]. Stockholm: Rabén Et Sjögren. 2015 Edition.

LINDGREN, A., WIKLAND, I. (1983). Titta, Madicken, det snöar! [Look, Madicken, it's snowing!]. Stockholm: Rabén \&t Sjögren. 2016 Edition.

LINDGREN, B., ERIKSSON, E. (1980-1990). Den Vilda Bebin [The Wild Baby]. Book series. Stockholm: Rabén \& Sjögren. 1994 Edition.

LINDGREN, B., ERIKSSON, E. (1981-2013). Max. Book series. Stockholm: Rabén \& Sjögren. 2014-2015 Edition.

LINDSTRÖM, E. (1997). Limpan är sugen. [Limpan is craving]. Stockholm: En Bok För Alla. 2017 Edition.

LUNDBORG, A., TOLLERUP-GRKOVIC, M. (1999). Malins mamma gifter sig med Lisa
[Malin's mum marries Lisa]. Stockholm: Eriksson \& Lindgren.

LUNDOVIST, J., JOHANSSON, B. (2012). Kivi \&t Monsterhund [Kivi and Monsterdog]. Linköping: Olika.

NILSSON, U., TIDHOLM, A. (2002). Adjö, herr Muffin [Goodbye, Mr Muffin]. Stockholm: Bonnier Carlsen. 2004 Edition.

NILSSON, U., ERIKSSON, E. (2006). Alla döda små djur [All the small dead animals]. Stockholm: Bonnier Carlsen.

NILSSON, U., ERIKSSON, E. (2008). Farmors alla pengar [All of grandma's money]. Stockholm: Bonnier Carlsen.

NORDOVIST, S. (1984-2016). Pettson och Findus [Pettson and Findus]. Book series. Bromma: Opal AB.

NORDOVIST, S. (2018). Hundpromenaden [The dog walk]. Bromma: Opal AB.

NYSTRÖM, J. (1882). Barnkammarens bok. [The nursery book]. Stockholm: Fahlcrantz. 1967 Edition.

RUEJAS, N. (2017) Låtsasheten [Fantasy]. Stockholm: Urax.

SENDAK, M. (1963). Where the Wild Things Are. New York: Harper Collins. 2012 Edition.

STALFELT, P. (1996). Hårboken [Hair book]. Stockholm: Eriksson \&t Lindgren. 2011 Edition.

STALFELT, P. (2012). Vem är du? [Who are you?]. Stockholm: Rabén \&t Sjögren.

SUMMANEN, E. (2015). Familjeboken [The family book]. Stockholm: Vombat Förlag.

VEGNA, S., JÖNSSON, M. (2017). Jag kom hit på ett litet blad [I came here on a little leaf]. Trollhättan: Kikkuli Förlag.

WIESLANDER, T., WIESLANDER, J., NORDOVIST, S. (1993-2018). Mamma Mu. [Mama Moo]. Book series. Stockholm: Natur \& Cultur (1993-2005), Rabén \& Sjögren (20052018).

WIKLAND, I. (2012). Sotis [Cutie]. Stockholm: Bromberg. 
WIRSÉN, S. (2005-2016). Vem [Who]. Book series. Stockholm: Bonnier Carlsen.

\section{Secondary sources}

BADER, B. (1976). American Picture books from Noah's Ark to the Beast Within. London: Macmillan.

DRUKER, E. (2008). Modernismens bilder: den moderna bilderboken i Norden [Pictures of modernism: the modern picture book in the Nordic countries]. Stockholm: Makadam Förlag.

DRUKER, E. (2010). Picture books and Trojan horses. In Colomer, T., KümmerlingMeibauer, B. and Silva-Díaz, C. (Eds.), New directions in Picturebook Research (pp. 139-149). London: Routledge.

DRUKER, E. (2018). Var befinner sig den svenska bilderboksforskningen? [Where is the Swedish picturebook research?]. Barnboken -tidskrift för barnlitteraturforskning [Barnboken -Journal for children's literature research]. Volume 41 (pp 1-14)

FRIDELL, L. (1977). Bilden i barnboken [The picture on children's books]. Gothenburg: Stegeland.

HALLBERG, K. (1982). Litteraturvetenskapen och bilderboksforskningen [Literary studies and picture book research]. Tidskrift för litteraturvetenskap [Literary Studies Magazine]. Volume 3-4 (pp. 163-168).

HALLBERG, K., WESTIN, B. (1985). I bilderbokens värld [In picture books' world]. Stockholm: LiberFörlag.

KUMMERLING-MEIBAUER, B. (2017). The Routledge Companion to Picture books. London: Routledge.

KÅRELAND, L. (2002). Bilderboken. In Lund, H. (Ed.), Intermedialitet. Ord, bild och ton i samspel [Intermediality. Word, image and tone in interaction]. Lund: Studentlitteratur.

KÅRELAND, L. (2008). Barnlitteraturensutveckling i Sverige [The development of children's literature in Sweden]. Litteraturbanken. Retrieved on $17^{\text {th }}$ January 2019 from: https://litteraturbanken.se/ $\mathrm{red} /$ presentationer/specialomraden/ BarnlitteraturensUtvecklingISverige.pdf

KÅRELAND, L. (2013). The story of Swedish picture books. In Lagercrantz Spindler, Y. (Ed.), Contemporary Swedish illustrators. Sweden guests of honour in Bologna 2013. Stockholm: Swedish Arts Council (pp. 7-21).

MOYA, A., PINAR, M. (2007). La interacción texto/ imagen en el cuento ilustrado. Un análisis multimodal [The interaction text/image in the illustrated book. A multimodal analysis]. OCNOS, 3, 21-38.

NIKOLAJEVA, M. (2000). Bilderbokens pusselbitar [Picture book's puzzle pieces]. Lund: Studentlitteratur.

NIKOLAJEVA, M., SCOT, C. (2001). How picture books work. London: Routledge. 2006 Edition.

NODELMAN, P. (2017). More words about pictures. London: Routledge.

PERSSON, M. (2006, December). Bildens betydelse i barnboken [The meaning of the picture in the children's book]. Retrieved on $5^{\text {th }}$ August 2018 from: http://hdl.handle. net/2043/3922

RHEDIN, U. (1992). Bilderboken -på väg mot en teori [Picture book - towards a theory]. Stockholm: Alfabeta Bokförlag. 2001 Edition.

RHEDIN, U., OSCAR K., ERIKSSON, E. (2013). En fanfar för bilderboken [A fanfare for picture books]. Stockholm: Alfabeta Bokförlag.

SVENSKA AKADEMIENS ORDLISTA (2018). Hen. Retrieved on $12^{\text {th }}$ November 2018 from: https://svenska.se/tre/?sok=henctpz=2

SVENSKA BARNBOKSINSTITUTET (2018). Bokprovning på Svenska barnboksinstitutet: en dokumentation Årgång 2017: 21 mars-17 maj 2018. [Book tasting at the 
Swedish Institute for Children's Books: a TORPPA, H. (2006). Om samspelet mellan documentation. Year 2017: March 21 ${ }^{\text {st }}$ May $\left.17^{\text {th }}, 2018\right]$.

Retrieved on $20^{\text {th }}$ January 2019 from: text och bild i två moderna svenska https://www.barnboksinstitutet.se/ bilderböcker med döden som tema [0n the interaction between text and picture wp-content/uploads/2018/09/2017$\%$ C3\%A5rs-utgivning-dokumentation.pdf in two modern picture books with death as a theme]. Retrieved on 17th August 2018 from: http://tampub.uta.fi/ handle/10024/93528. 